\title{
Labeling of Bifunctional Chelating Agent, MAG3, with Carrier-free ${ }^{188}$ Re
}

\author{
Kazuyuki Hashimoto, ${ }^{*}, \mathrm{a}$ W. H. B. B. Wan Kamal, ${ }^{\mathrm{b}}$ and Hiromitsu Matsuoka ${ }^{\mathrm{a}}$ \\ ${ }^{a}$ Department of Research Reactor, Japan Atomic Energy Research Institute, Tokai-mura, Ibaraki-ken 319-1195, \\ Japan \\ ${ }^{\mathrm{b}}$ Malaysian Institute for Nuclear Technology Research, Bangi, 43000 Kajang, Selangor, Malaysia
}

Received: July 31, 2005; In Final Form: September 30, 2005

\begin{abstract}
The labeling of MAG3 with carrier-free ${ }^{188} \mathrm{Re}$ from the ${ }^{188} \mathrm{~W} /{ }^{188} \mathrm{Re}$ generator was investigated by the direct $\mathrm{Sn}$ reduction (solid-phase synthesis) and the indirect labeling method using citrate or gluconate as a transfer ligand. Optimum pH range were 12.1-12.6 for the direct Sn reduction, 2-5 for the use of citrate and 2.6-3 for the use of gluconate. Although the differences of the optimum conditions such as $\mathrm{pH}$ and reaction time at room temperature were observed by using a different transfer ligand, the labeling yield of ${ }^{188}$ Re-MAG3 synthesized by the all methods was over $90 \%$ under the optimum conditions. The solid-phase synthesis requires the operation under a stream of nitrogen gas and the evaporation of solvent. On the other hand, the method using a transfer ligand is one-pot preparation by just heating a reaction mixture. Thus, judging from the ease of operations, the method using a transfer ligand is more convenient.
\end{abstract}

\section{Introduction}

The radioisotopes of rhenium $\left({ }^{186} \mathrm{Re}\right.$ and $\left.{ }^{188} \mathrm{Re}\right)$ are attractive radionuclides for radiotherapy because of their energetic beta particles and gamma rays suitable for imaging. ${ }^{1-3}$ Especially, rhenium-188 has an advantage of easy availability, because ${ }^{188} \mathrm{Re}$ can be obtained in a carrier-free level from a ${ }^{188} \mathrm{~W} /{ }^{188} \mathrm{Re}$ generator. Oxorhenium(V) and oxotechnetium(V) complexes with quadridentate ligands such as $\mathrm{N}_{3} \mathrm{~S}$ and $\mathrm{N}_{2} \mathrm{~S}_{2}$ ligands are often used as radiopharmaceuticals. ${ }^{4,5}$ Among them, mercaptoacetyltriglycine, MAG3 $\left(\mathrm{N}_{3} \mathrm{~S}\right.$ ligand, Figure 1) labeled with ${ }^{99 \mathrm{~m}} \mathrm{Tc}$ is widely used as a renal imaging agent. Furthermore, MAG3 is a useful bifunctional ligand in labeling biomolecules (such as monoclonal antibodies ${ }^{6,7}$ and peptides ${ }^{8}$ ) with ${ }^{99 \mathrm{~m}} \mathrm{Tc}$ for radioimmunoscintigraphy of cancer and with ${ }^{186,188} \mathrm{Re}$ for radioimmunotherapy of cancer.

In this work, the labeling of MAG3 with carrier-free ${ }^{188} \mathrm{Re}$ from a ${ }^{188} \mathrm{~W} /{ }^{188} \mathrm{Re}$ generator was investigated in detail. The ${ }^{188}$ Re-MAG3 complex was synthesized by the direct $\mathrm{Sn}$ reduction (solid-phase synthesis) ${ }^{6}$ and by the indirect labeling method using a transfer ligand (citrate ${ }^{8}$ or gluconate). The dependence of the labeling yield upon the reaction conditions such as the concentrations of tin(II) chloride dihydrate as a reducing agent, S-benzoyl MAG3 and the transfer ligand, $\mathrm{pH}$, temperature, reaction time and the addition of a carrier (final concentration: $20 \mu \mathrm{g} \mathrm{Re} / \mathrm{mL}$ ) was examined.

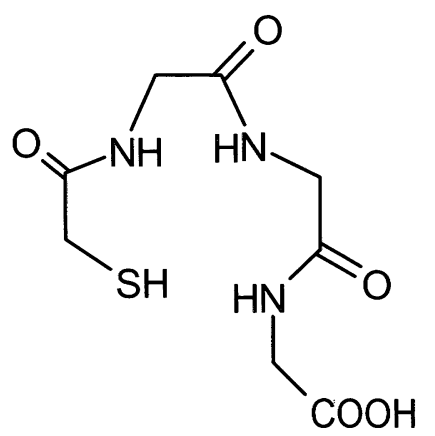

Figure 1. Chemical structure of MAG3.

*Corresponding author. E-mail: hashimoto.kazuyuki@jaea.go.jp. FAX: +81-29-282-5932.

\section{Experimental}

2.1. Production of ${ }^{188} \mathbf{W} /{ }^{188}$ Re generator. Typically $25-35$ mg of enriched ${ }^{186} \mathrm{~W}$ as $\mathrm{WO}_{3}(99.79 \%$ enrichment: Euriso-top, France) was irradiated for 26-52 days in JAERI JMTR (a thermal neutron flux of $\left.2.7 \times 10^{14} \mathrm{n} \mathrm{cm}^{-2} \mathrm{~s}^{-1}\right){ }^{9}$ The irradiated target was allowed to stand for more than 4 weeks for ${ }^{187} \mathrm{~W}$ decay. The ${ }^{188} \mathrm{~W} /{ }^{188} \mathrm{Re}$ generator was prepared by the alumina column system. ${ }^{10}$ The irradiated $\mathrm{WO}_{3}$ was dissolved in $2 \mathrm{M} \mathrm{NaOH}$. The $\mathrm{pH}$ of the ${ }^{188} \mathrm{~W}$ solution was adjusted to about 2 using $\mathrm{HCl}$. This solution was passed through the alumina column $(10 \times 60$ $\mathrm{mm}$; BIO-RAD, AG-4, 100-200 mesh), which was conditioned with $0.01 \mathrm{M} \mathrm{HCl}$. The column was then washed with normal saline. Rhenium-188 was eluted with normal saline after the equilibrium between ${ }^{188} \mathrm{~W}$ and ${ }^{188} \mathrm{Re}$ had almost reached. Rhenium-188 solution $(0.2-3 \mathrm{MBq} / \mathrm{mL})$ was obtained from the generator in a saline solution and was used for labeling purposes without further purification.

2.2. Synthesis of ${ }^{188}$ Re-MAG3 complex. S-Benzoyl-MAG3 (S-Bz-MAG3) was supplied from Center for Development of Radioisotopes and Radiopharmaceuticals, BATAN (the National Nuclear Energy Agency, Indonesia). S-Triphenylmethyl-MAG3 (S-Tr-MAG3) was a gift from Prof. Arano, Chiba University. All other chemicals used were of guaranteed reagent grade.

(a) Direct $\mathrm{Sn}$ reduction (solid-phase synthesis) ${ }^{6}$

To $150 \mu \mathrm{L}$ of $1 \mathrm{M} \mathrm{Na}_{2} \mathrm{CO}_{3}, 500 \mu \mathrm{L}$ of a ${ }^{188} \mathrm{Re}$ solution from the generator, $150 \mu \mathrm{L}$ of a freshly prepared $\mathrm{Na}_{2} \mathrm{SO}_{3}$ solution $(100$ $\mathrm{mg} / \mathrm{mL}), 75 \mu \mathrm{L}$ of $\mathrm{HCl}$ or $\mathrm{NaOH}$ solution for $\mathrm{pH}$ adjustment, 25 $\mu \mathrm{L}$ of S-Bz-MAG3 $\left(2 \mathrm{mg} / \mathrm{mL}\right.$ acetonitrile/ $\left./ \mathrm{H}_{2} \mathrm{O}, 9: 1\right)$ and 100 $\mu \mathrm{L}$ of a freshly prepared $2 \mathrm{mg} / \mathrm{mL}$ tin(II) chloride dihydrate aqueous solution were added. The reaction mixture in a closed vial was heated in boiling water for $10 \mathrm{~min}$ and evaporated to dryness under a stream of $\mathrm{N}_{2}$ gas. The mixture was further heated for another $15 \mathrm{~min}$. After cooling on ice, the mixture was reconstituted with $500 \mu \mathrm{L}$ of water. The $\mathrm{pH}$ was brought in 5.7 to 6.3 with $490 \mu \mathrm{L}$ of $1 \mathrm{~N} \mathrm{H}_{2} \mathrm{SO}_{4}$ and $25-70 \mu \mathrm{L}$ of $1 \mathrm{M}$ $\mathrm{Na}_{2} \mathrm{CO}_{3}$, and the solution was filtered through a $0.22 \mu \mathrm{m}$ filter. Radiochemical yields of ${ }^{188}$ Re-MAG3 were determined by HPLC. Free MAG3 was also used instead of S-Bz-MAG3. Free MAG3 was prepared from S-Tr-MAG3 by treating with trifluoroacetic acid and triethylsilane just before radiolabeling. 
(b) Citrate as a transfer ligand ${ }^{8}$

To $0.55 \mathrm{mg}$ of S-Bz-MAG3, $450 \mu \mathrm{L}$ of solution for $\mathrm{pH}$ adjustment $(0.1 \sim 0.6 \mathrm{M} \mathrm{HCl}, 0.2 \mathrm{M} \mathrm{NaOH}, 0.2 \mathrm{M}$ acetic aid and/or 0.2 $\mathrm{M}$ sodium acetate) and $450 \mu \mathrm{L}$ of a freshly prepared $\mathrm{SnCl}_{2} \cdot 2 \mathrm{H}_{2} \mathrm{O}$ in $0.1 \mathrm{M}$ citrate-buffer $(\mathrm{pH}=5)$ were added. The reaction mixture was vigorously stirred by ultrasonic waves and $300 \mu \mathrm{L}$ of a ${ }^{188} \mathrm{Re}$ solution from the generator was added. The final concentration of Re varied from carrier-free levels to $20 \mu \mathrm{g} \mathrm{Re} / \mathrm{mL}$ $\left(1.07 \times 10^{-4} \mathrm{M}\right)$ by adding $\mathrm{NH}_{4} \mathrm{ReO}_{4}$ to the ${ }^{188} \mathrm{Re}$ solution. After stirring the solution by vortex, the mixture in a closed vial was allowed to react in boiling water or at room temperature for $1 \mathrm{~h}$. The mixture was cooled on ice for 5-10 min. After the solution was filtered through a $0.22 \mu \mathrm{m}$ filter, radiochemical yields of ${ }^{188}$ Re-MAG3 were determined by HPLC.

The labeling yield of ${ }^{188} \mathrm{Re}$-citrate was determined by silica gel TLC (Merck No. 5735/acetone) and silica gel ITLC (Gelman Sciences/0.9\% NaCl) as well as ${ }^{99 m}$ Tc-gluconate. ${ }^{11}$ The distribution of ${ }^{188} \mathrm{Re}$ in TLC and ITLC was measured with a radioanalytic imaging system (AMBIS-100).

(c) Gluconate as a transfer ligand

To $0.55 \mathrm{mg}$ of S-Bz-MAG3, $450 \mu \mathrm{L}$ of solution for $\mathrm{pH}$ adjustment $(0.0 \sim 10.1 \mathrm{M} \mathrm{HCl}, 0.01-0.2 \mathrm{M} \mathrm{NaOH}$ and/or $0.2 \mathrm{M}$ sodium acetate), $225 \mu \mathrm{L}$ of sodium gluconate aqueous solution and $225 \mu \mathrm{L}$ of a freshly prepared $\mathrm{SnCl}_{2} \cdot 2 \mathrm{H}_{2} \mathrm{O}$ in $0.1 \mathrm{M} \mathrm{HCl}$ were added. The reaction mixture was vigorously stirred by ultrasonic waves and $300 \mu \mathrm{L}$ of a ${ }^{188} \mathrm{Re}$ solution from the generator was added. The final concentration of Re varied from carrier-free levels to $20 \mu \mathrm{g} \mathrm{Re} / \mathrm{mL}$ by adding $\mathrm{NH}_{4} \mathrm{ReO}_{4}$ to the ${ }^{188} \mathrm{Re}$ solution. The mixture in a closed vial was allowed to react in boiling water or at room temperature for $1 \mathrm{~h}$. The white precipitation was occurred at $\mathrm{pH}<11$. After the $\mathrm{pH}$ of the solution was brought to about 12 by adding $\mathrm{NaOH}$, the precipitation was dissolved. Therefore, the same volume of $0.1 \mathrm{M}$ $\mathrm{NaOH}$ was added to the reaction mixture just before the HPLC analysis when the precipitation had occurred. Radiochemical yields of ${ }^{188}$ Re-MAG3 were determined by HPLC.

2.3. HPLC analysis. The liquid chromatograph used was a Waters 2690 separations module equipped with a Waters 996 photodiode array detector and a radio-HPLC detector (Packard Radiomatic 515TR). The column was kept at $25^{\circ} \mathrm{C}$. Radiochemical yield of ${ }^{188} \mathrm{Re}-\mathrm{MAG} 3$ was determined by reversed phase HPLC (Hypersil BDS-5C18, $4.6 \times 150 \mathrm{~mm}$, Chemco Science Co., Japan) using $4 \% \mathrm{EtOH}-0.01 \mathrm{M}$ phosphate buffer ( $\mathrm{pH}$ $=7$ ). The flow rate was $1.0 \mathrm{~mL} / \mathrm{min}$. Typical chromatograms are shown in Figure 2. Retention times of ${ }^{188} \mathrm{ReO}_{4}{ }^{-}$and ${ }^{188} \mathrm{Re}$ MAG3 were $2.4 \mathrm{~min}$ and 3.7-3.9 min, respectively.

2.4. Stability studies of ${ }^{188} \mathrm{Re}-\mathrm{MAG} 3$ complex. The $\mathrm{pH}$ of ${ }^{188}$ Re-MAG3 solution $(100 \mu \mathrm{L})$ was changed to higher values (pH 2-14) by adding $400 \mu \mathrm{L}$ of $\mathrm{HCl}, \mathrm{NaOH}$ and/or sodium

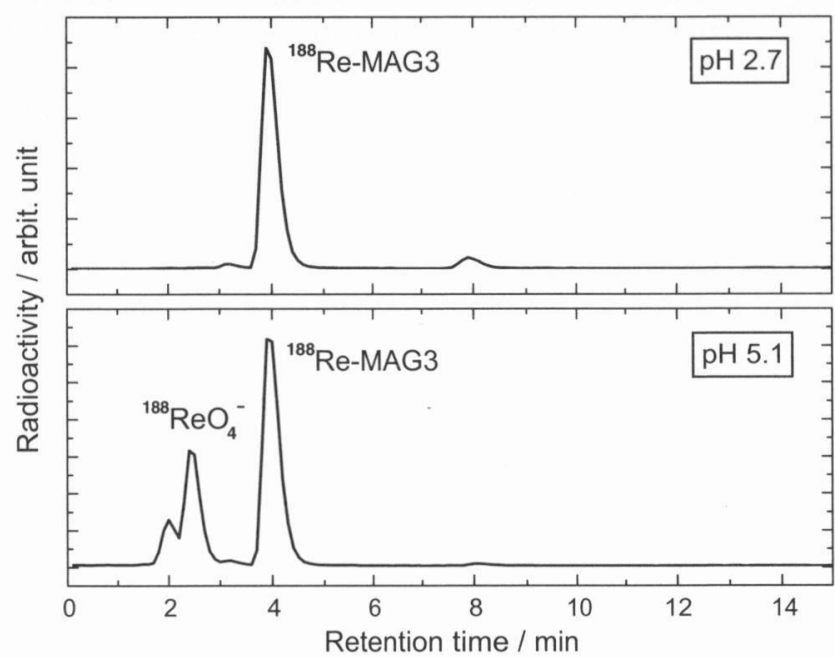

Figure 2. Typical chromatograms of carrier-free ${ }^{188}$ Re-MAG3 synthesized by using citrate at different $\mathrm{pH}$. acetate solution for $\mathrm{pH}$ adjustment. At regular intervals (1 hour to 70 hours), the radiochemical yield of ${ }^{188}$ Re-MAG3 was determined by HPLC as mentioned earlier.

\section{Results and Discussion}

3.1. Direct Sn reduction (solid-phase synthesis). By just heating the reaction mixture, no formation of ${ }^{188}$ Re-MAG3 was observed. When the solution was evaporated at $100{ }^{\circ} \mathrm{C}$ under a stream of $\mathrm{N}_{2}$ until dry and heating continued, ${ }^{188}$ Re-MAG3 formation occurred. This phenomenon would be due to increase of concentration of the reagents $\left(\mathrm{SnCl}_{2}, \mathrm{MAG} 3\right)$ during the evaporation process.

The yield of ${ }^{188}$ Re-MAG3 increased with the concentration of tin chloride and reached a constant value at $2 \mathrm{mg} / \mathrm{mL}$ of tin(II) chloride dehydrate in the initial solution. The concentration of tin chloride was fixed at $2 \mathrm{mg} / \mathrm{mL}$ in this work $(0.2$ $\mathrm{mg} / \mathrm{mL}$ in the initial reaction mixture), however the concentration in the literature ${ }^{6}$ using ${ }^{186} \mathrm{Re}$ was $1 \mathrm{mg} / \mathrm{mL}$ of tin(II) chloride dehydrate solution.

The yields of ${ }^{188} \mathrm{Re}-\mathrm{MAG} 3$ were $83 \%$ and $89 \%$ at $\mathrm{pH} 12.5$, when $1 \mathrm{mg} / \mathrm{mL}$ and $2 \mathrm{mg} / \mathrm{mL}$ of S-Bz-MAG3 solution were used respectively. The concentration of S-Bz-MAG3 was fixed at $2 \mathrm{mg} / \mathrm{mL}$ in this work $(0.05 \mathrm{mg} / \mathrm{mL}$ in the initial reaction mixture), however the concentration in the literature ${ }^{6}$ was 1 $\mathrm{mg} / \mathrm{mL}$ of S-Bz-MAG3 solution.

The dependence of the labeling yield of ${ }^{188} \mathrm{Re}-\mathrm{MAG} 3$ on $\mathrm{pH}$ in the initial reaction mixture was shown in Figure 3. The yield was more than $90 \%$ in the $\mathrm{pH}$ range $12.1-12.6$. Our results are somewhat different from the results in the literature ${ }^{6}$ that the optimum $\mathrm{pH}$ was 11.7. The formation of ${ }^{188} \mathrm{Re}-\mathrm{MAG} 3$ by the direct $\mathrm{Sn}$ reduction consists of some reactions such as the deprotection of benzoly-group from S-Bz-MAG3, the reduction of $\operatorname{Re}(\mathrm{VII})$ to $\operatorname{Re}(\mathrm{V})$ by tin chloride and the reaction of MAG3 and $\operatorname{Re}(\mathrm{V})$. The $\mathrm{pH}$ dependence of the yield of ${ }^{188} \mathrm{Re}$ MAG3 may reflect individual $\mathrm{pH}$ dependences in these reactions. The yield of ${ }^{188} \mathrm{Re}-\mathrm{MAG} 3$ has the maximum value in the alkaline $\mathrm{pH}$ region, as shown in Figure 3. Generally, the deprotection of benzoly-group from S-Bz-MAG3 is carried out in $\mathrm{NaOH}$ solution. If the deprotection process is important for determination of the $\mathrm{pH}$ dependence of the ${ }^{188} \mathrm{Re}-\mathrm{MAG} 3$ yield, the $\mathrm{pH}$ dependence will be changed by using free MAG3 instead of S-Bz-MAG3. As shown in Figure 3, the pH dependence using free MAG3 produced from S-Tr-MAG3 was almost the same as that using S-Bz-MAG3. Thus, the deprotection of benzoyl group is less important for determination of the $\mathrm{pH}$ dependence of the ${ }^{188} \mathrm{Re}-\mathrm{MAG} 3$ yield.

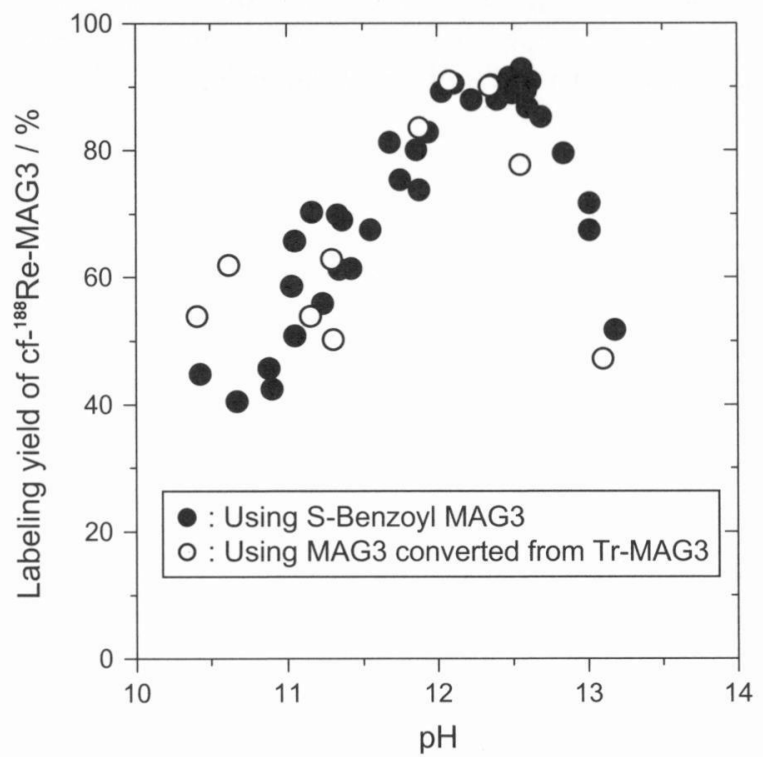

Figure 3. Influence of $\mathrm{pH}$ on the labeling yield of carrier-free ${ }^{188} \mathrm{Re}$ MAG3 prepared by the solid-phase synthesis. 


\subsection{Indirect labeling method using a transfer ligand.}

3.2.1. Effect of the concentration of S-Bz-MAG3. Citrate: The influence of S-Bz-MAG3 concentration $(0.45-1.67 \mathrm{mg} / \mathrm{mL})$ in the reaction mixture was studied at $\mathrm{pH} 1.7-1.8,\left[\mathrm{SnCl}_{2} \cdot 2 \mathrm{H}_{2} \mathrm{O}\right]$ $=2.25 \mathrm{mg} / \mathrm{mL}$. The labeling yield of ${ }^{188} \mathrm{Re}-\mathrm{MAG} 3$ was almost constant (about 90\%) for the carrier-free ${ }^{188} \mathrm{Re}$. However, the yield increased with the concentration of S-Bz-MAG3 and reached a constant value (about $90 \%$ ) at $1.3 \mathrm{mg} / \mathrm{mL}$ for the carrier-added ${ }^{188} \operatorname{Re}(20 \mu \mathrm{g} \mathrm{Re} / \mathrm{mL})$. Higher concentration of SBz-MAG3 was required to obtain more than $90 \%$ of the yield for the carrier-added ${ }^{188} \mathrm{Re}$.

Gluconate: The influence of S-Bz-MAG3 concentration $(0.11-1.66 \mathrm{mg} / \mathrm{mL})$ in the reaction mixture was studied at $\mathrm{pH} 3$, $\left[\mathrm{SnCl}_{2} \cdot 2 \mathrm{H}_{2} \mathrm{O}\right]=2.25 \mathrm{mg} / \mathrm{mL}$. The labeling yield of ${ }^{188} \mathrm{Re}-\mathrm{MAG} 3$ was almost constant (about $90 \%$ ) for the carrier-free ${ }^{188} \mathrm{Re}$. However, the yield increased with the concentration of S-BzMAG3 and reached a constant value (about 90\%) at $0.8 \mathrm{mg} / \mathrm{mL}$ for the carrier-added ${ }^{188} \mathrm{Re}$.

The results indicated almost the same tendency for citrate and gluconate.

3.2.2. Effect of the concentration of tin chloride. Citrate: The influence of $\mathrm{SnCl}_{2} \cdot 2 \mathrm{H}_{2} \mathrm{O}$ concentration $(0.38-4.5 \mathrm{mg} / \mathrm{mL})$ in the reaction mixture was studied at $\mathrm{pH} 1.6-1.9$, [S-BzMAG3] $=0.45 \mathrm{mg} / \mathrm{mL}$. The labeling yield of ${ }^{188} \mathrm{Re}-\mathrm{MAG} 3$ was about $90 \%$ for the carrier-free ${ }^{188} \mathrm{Re}$ and about $80 \%$ for the carrier-added ${ }^{188} \mathrm{Re}$ not less than $1.1 \mathrm{mg} / \mathrm{mL}\left(4.9 \times 10^{-3} \mathrm{M}\right)$. The yield decreased below $0.38 \mathrm{mg} / \mathrm{mL}\left(1.7 \times 10^{-3} \mathrm{M}\right)$.

Gluconate: The influence of $\mathrm{SnCl}_{2} \cdot 2 \mathrm{H}_{2} \mathrm{O}$ concentration $(0.59-9.0 \mathrm{mg} / \mathrm{mL})$ in the reaction mixture was studied at $\mathrm{pH}$ $2.8-3.1$, [S-Bz-MAG3] $=0.46 \mathrm{mg} / \mathrm{mL}$. The labeling yield of ${ }^{188} \mathrm{Re}-\mathrm{MAG} 3$ was about $90 \%$ in the range $1-3 \mathrm{mg} / \mathrm{mL}$ for both the carrier-free and the carrier-added ${ }^{188} \mathrm{Re}$. A precipitate was formed and the yield decreased more than $3 \mathrm{mg} / \mathrm{mL}$. At $\mathrm{pH}$ 12 , the yield increased $\left(36-38 \%\right.$ at $1.1 \mathrm{mg} / \mathrm{mL}$ of $\mathrm{SnCl}_{2}, 70-$ $72 \%$ at $9.0 \mathrm{mg} / \mathrm{mL}$ of $\mathrm{SnCl}_{2}$ ) with the concentration of tin chloride for both the carrier-free and the carrier-added ${ }^{188} \mathrm{Re}$.

3.2.3. Effect of $\mathrm{pH}$. Citrate: The influence of $\mathrm{pH}$ on the labeling yield was investigated at $\left[\mathrm{SnCl}_{2} \cdot 2 \mathrm{H}_{2} \mathrm{O}\right]=2 \mathrm{mg} / \mathrm{mL}$, $[\mathrm{S}-\mathrm{Bz}$ MAG3] $=0.45 \mathrm{mg} / \mathrm{mL}$ for the carrier-free ${ }^{188} \mathrm{Re}, 1.67 \mathrm{mg} / \mathrm{mL}$ for the carrier-added ${ }^{188} \mathrm{Re}$, as shown in Figure 4. The maximum labeling yield (more than 90\%) was obtained in the $\mathrm{pH}$ range $2-5$ and the yield decreased sharply above $\mathrm{pH} 5$.

Gluconate: The influence of $\mathrm{pH}$ on the labeling yield was investigated at $\left[\mathrm{SnCl}_{2} \cdot 2 \mathrm{H}_{2} \mathrm{O}\right]=2 \mathrm{mg} / \mathrm{mL},[\mathrm{S}-\mathrm{Bz}-\mathrm{MAG} 3]=0.46$ $\mathrm{mg} / \mathrm{mL}$, as shown in Figure 5. The maximum labeling yield (more than 90\%) was obtained in the $\mathrm{pH}$ range 2.6-3 and the

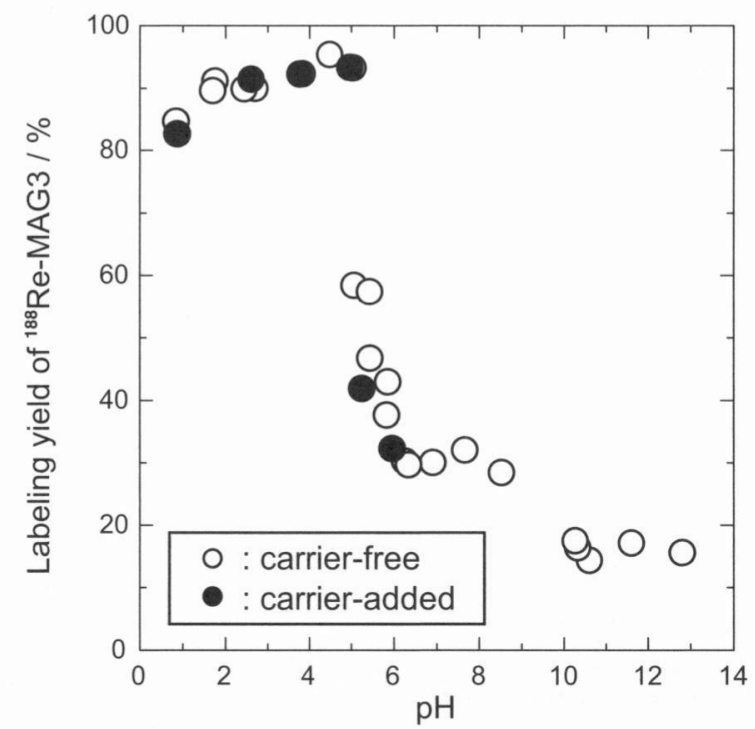

Figure 4. Influence of $\mathrm{pH}$ on the labeling yield of ${ }^{188} \mathrm{Re}-\mathrm{MAG} 3$ prepared by using citrate as a transfer ligand $\left(\left[\mathrm{SnCl}_{2} \cdot 2 \mathrm{H}_{2} \mathrm{O}\right]=2 \mathrm{mg} / \mathrm{mL}\right.$, [S-Bz-MAG3] $=0.45 \mathrm{mg} / \mathrm{mL}$ for the carrier-free ${ }^{188} \mathrm{Re}, 1.67 \mathrm{mg} / \mathrm{mL}$ for the carrier-added ${ }^{188} \mathrm{Re}$ ). yield decreased sharply above $\mathrm{pH} 3$. In the alkaline region $\mathrm{pH}$ $10-13$ ), the labeling yield using gluconate was higher than that using citrate. Furthermore, the labeling yield using gluconate increased with the concentrations of tin chloride (as described above) and gluconate (as described later).

The $\mathrm{pH}$ dependence of the yield of ${ }^{188} \mathrm{Re}-\mathrm{MAG} 3$ by the indirect labeling method may reflect some factors such as the deprotection of benzoly-group from S-Bz-MAG3, the reduction of $\operatorname{Re}(\mathrm{VII})$ to $\operatorname{Re}(\mathrm{V})$ by tin chloride, the reaction of MAG3 and $\operatorname{Re}(\mathrm{V})$, the formation of $\operatorname{Re}(\mathrm{V})-\mathrm{X}$ and the reaction of MAG3 and $\operatorname{Re}(\mathrm{V})-\mathrm{X}(\mathrm{X}=$ transfer ligand). The $\mathrm{pH}$ dependence of the ${ }^{188}$ Re-MAG3 labeling yield was influenced by a transfer ligand as mentioned above. And, it was reported that the optimum $\mathrm{pH}$ was $5-6$ for ${ }^{188}$ Re-MAG3 prepared by using sodium potassium tartrate as a transfer ligand. ${ }^{12}$ It was different from our results using citrate or gluconate. Thus, the reactions in which a transfer ligand participates such as the formation of $\operatorname{Re}(\mathrm{V})-\mathrm{X}$ and the reaction of MAG3 and $\operatorname{Re}(\mathrm{V})-\mathrm{X}$ would be important for determination of the $\mathrm{pH}$ dependence. Furthermore, it would support the above induction that the $\mathrm{pH}$ dependence (such as the optimum $\mathrm{pH}$ range) of the labeling yield of ${ }^{186,188} \mathrm{Re}$-citrate ${ }^{13}$ as shown in Figure 6 was similar to that of ${ }^{188}$ Re-MAG3 prepared by using citrate (Figure 4).

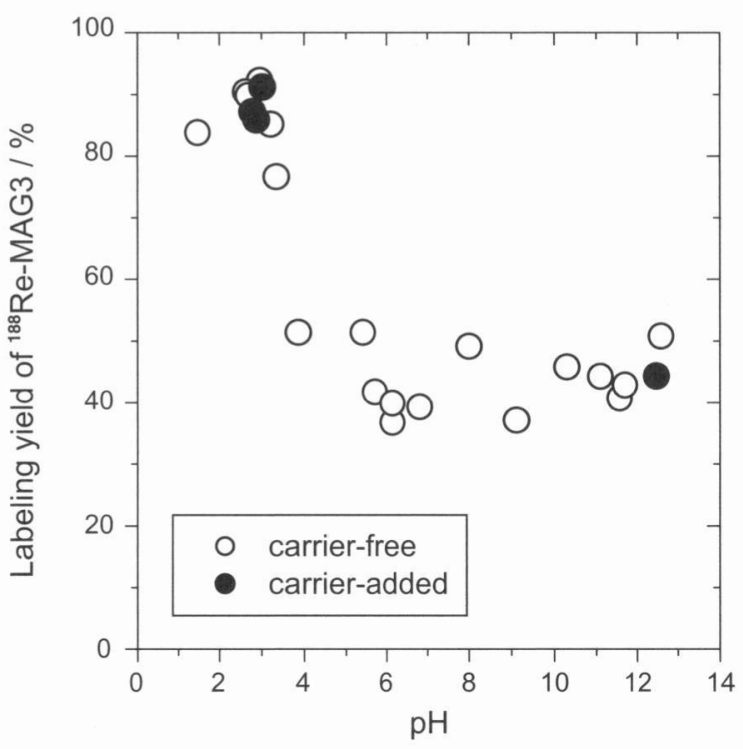

Figure 5. Influence of $\mathrm{pH}$ on the labeling yield of ${ }^{188} \mathrm{Re}-\mathrm{MAG} 3$ prepared by using gluconate as a transfer ligand $\left(\left[\mathrm{SnCl}_{2} \cdot 2 \mathrm{H}_{2} \mathrm{O}\right]=2 \mathrm{mg}\right.$ ) $\mathrm{mL},[\mathrm{S}-\mathrm{Bz}-\mathrm{MAG} 3]=0.46 \mathrm{mg} / \mathrm{mL}$ ).

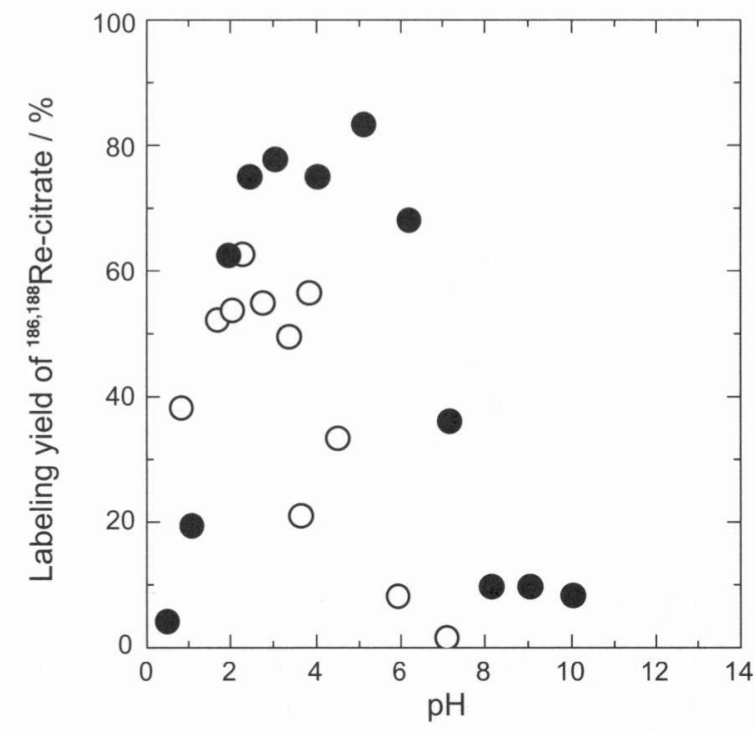

Figure 6. Influence of $\mathrm{pH}$ on the labeling yield of ${ }^{186,188} \mathrm{Re}$-citrate $(\mathrm{O}$ : This work $\left(\mathrm{cf}^{-188} \mathrm{Re},\left[\mathrm{SnCl}_{2} \cdot 2 \mathrm{H}_{2} \mathrm{O}\right]=2.25 \mathrm{mg} / \mathrm{mL}\right.$, [citrate] $=0.038$ $\mathrm{M})$, R. Koníŕová et al. $\left.\left({ }^{186} \mathrm{Re}\right)^{13}\right)$. 
Concentration of gluconate / $\mathrm{M}$

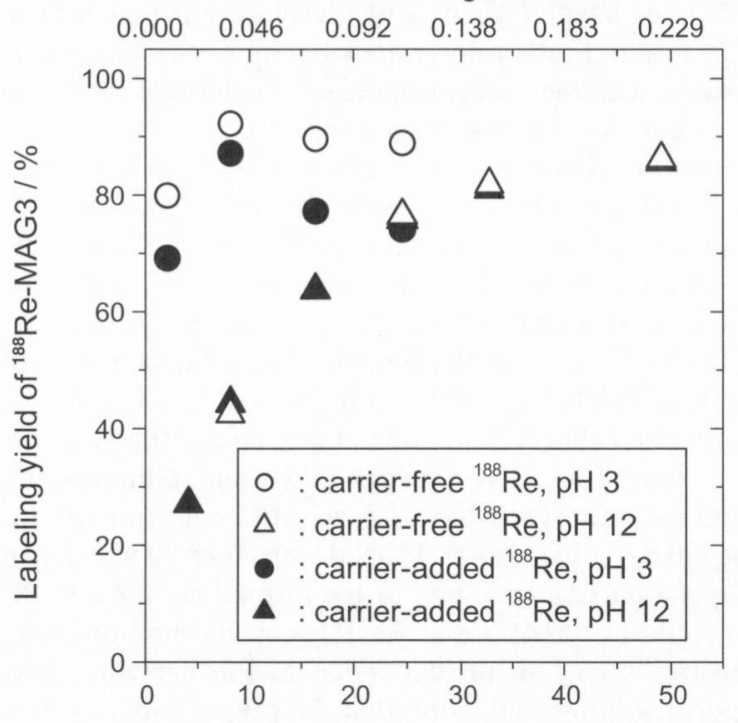

Concentration of sodium gluconate / $(\mathrm{mg} / \mathrm{mL})$

Figure 7. Influence of the concentration of gluconate on the labeling yield of ${ }^{188} \mathrm{Re}-\mathrm{MAG} 3$ prepared by using gluconate as a transfer ligand $\left(\left[\mathrm{SnCl}_{2} \cdot 2 \mathrm{H}_{2} \mathrm{O}\right]=2.25 \mathrm{mg} / \mathrm{mL},[\mathrm{S}-\mathrm{Bz}-\mathrm{MAG} 3]=0.46 \mathrm{mg} / \mathrm{mL}\right)$.

3.2.4. Effect of the concentration of a transfer ligand. Citrate: The influence of citrate concentration $(7.9$ and $39 \mathrm{mg} / \mathrm{mL}$, 0.038 and $0.19 \mathrm{M}$ ) was studied at $\mathrm{pH} 5.6,7.4,13-14,\left[\mathrm{SnCl}_{2} \cdot 2 \mathrm{H}_{2} \mathrm{O}\right]$ $=2.25 \mathrm{mg} / \mathrm{mL}$, [S-Bz-MAG3] $=0.45 \mathrm{mg} / \mathrm{mL}$. The labeling yield using $0.19 \mathrm{M}$ citrate was a little higher (5-10 points) than that using $0.038 \mathrm{M}$ citrate at all $\mathrm{pH}$.

Gluconate: The influence of gluconate concentration (2.0$49.1 \mathrm{mg} / \mathrm{mL}, 0.0094-0.225 \mathrm{M}$ ) was studied at $\mathrm{pH} 3$ and 12 , $\left[\mathrm{SnCl}_{2} \cdot 2 \mathrm{H}_{2} \mathrm{O}\right]=2.25 \mathrm{mg} / \mathrm{mL},[\mathrm{S}-\mathrm{Bz}-\mathrm{MAG} 3]=0.46 \mathrm{mg} / \mathrm{mL}$, as shown in Figure 7. The labeling yield at $\mathrm{pH} 3$ indicated a maximum at $8.2 \mathrm{mg} / \mathrm{mL}$ of gluconate. The labeling yield at $\mathrm{pH} 12$ increased up to $85 \%$ with the concentration of gluconate for both the carrier-free and the carrier-added ${ }^{188} \mathrm{Re}$.

3.2.5. Effect of reaction time and temperature. At the optimum $\mathrm{pH}(2.4-2.5$ for citrate and 2.8 -3.0 for gulconate), the labeling yield was more than $90 \%$ for $15 \mathrm{~min}$ in boiling water for the carrier-free ${ }^{188} \mathrm{Re}$. For the carrier-added ${ }^{188} \mathrm{Re}$, the reaction time in boiling water was required $60 \mathrm{~min}$ for citrate and $30 \mathrm{~min}$ for gluconate to obtain more than $90 \%$ of the yield. The labeling yield prepared at room temperature was lower than that in boiling water for both citrate and gluconate. The labeling yield using gluconate at $\mathrm{pH} 3$ for $30 \mathrm{~min}$ at room temperature was more than $88 \%$ for the carrier-free ${ }^{188} \mathrm{Re}$, however the labeling yield using citrate was lower than $15 \%$ under the same conditions.

3.3. Stability of ${ }^{188} \mathrm{Re}-\mathrm{MAG3}$. The influence of $\mathrm{pH}$ on the stability of the ${ }^{188} \mathrm{Re}-\mathrm{MAG} 3$ prepared by using citrate or gluconate under the optimum conditions was investigated. The $\mathrm{pH}$ of ${ }^{188} \mathrm{Re}-\mathrm{MAG} 3$ was changed to a higher value ( $\left.\mathrm{pH} 2-14\right)$. The decomposition of ${ }^{188} \mathrm{Re}-\mathrm{MAG} 3$ prepared by using citrate was observed only when the $\mathrm{pH}$ was over 12 , as shown in Figure 8. The survival $\{=$ (the amount after the $\mathrm{pH}$ change/the initial amount) $\times 100$ \} of carrier-free ${ }^{188}$ Re-MAG3 was over $97 \%$ at $\mathrm{pH}$ 6.7 and $94 \%$ at pH 11.3 even after 70 hours. The same results were obtained for ${ }^{188}$ Re-MAG3 prepared by using gluconate. Furthermore, there was no difference in stability between carrier-free ${ }^{188} \mathrm{Re}-\mathrm{MAG} 3$ and carrier-added one.

\section{Conclusion}

The labeling of MAG3 with carrier-free ${ }^{188} \mathrm{Re}$ from the ${ }^{188} \mathrm{~W} /{ }^{188} \mathrm{Re}$ generator was investigated. The labeling yield of ${ }^{188} \mathrm{Re}-\mathrm{MAG} 3$ synthesized by the direct $\mathrm{Sn}$ reduction (solid-phase synthesis) and the indirect labeling method using citrate or gluconate as a transfer ligand was over $90 \%$ under the optimum

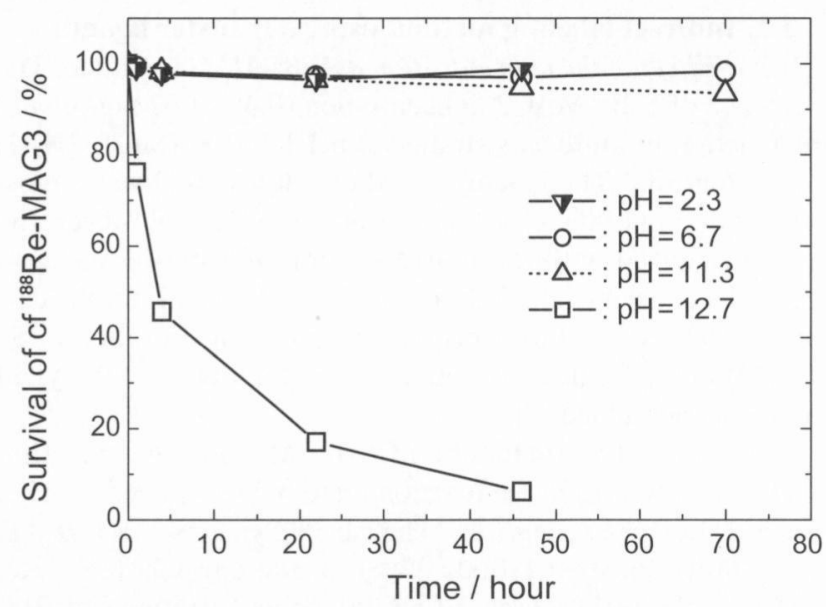

Figure 8. Stability of carrier-free ${ }^{188}$ Re-MAG3 prepared by using citrate

conditions. The solid-phase synthesis requires the operation under a stream of nitrogen gas and the evaporation of solvent. On the other hand, the method using a transfer ligand is one-pot preparation by just heating a reaction mixture. Thus, judging from the ease of operations, the method using a transfer ligand is more convenient. However, the solid-phase synthesis required the smaller amounts of the reagents (S-Bz-MAG3: $0.05 \mathrm{mg}$ per $1 \mathrm{~mL}$ of the reaction mixture, $\mathrm{SnCl}_{2} \cdot 2 \mathrm{H}_{2} \mathrm{O}: 0.2 \mathrm{mg}$ ) than the method using a transfer ligand (S-Bz-MAG3: $0.5 \mathrm{mg}$ per $1 \mathrm{~mL}$ of the reaction mixture, $\mathrm{SnCl}_{2} \cdot 2 \mathrm{H}_{2} \mathrm{O}: 1-2 \mathrm{mg}$ ) because the concentrations of the reagents in the solid-phase synthesis increased gradually during the evaporation process. The effect of $\mathrm{pH}$ on the labeling yield of ${ }^{188} \mathrm{Re}-\mathrm{MAG} 3$ was influenced by the difference of transfer ligands. Citrate works effectively in the acid $\mathrm{pH}$ region and gluconate dose in the alkaline $\mathrm{pH}$ region.

Acknowledgements. The authors are grateful to Prof. Yasushi Arano, Faculty of Pharmaceutical Sciences, Chiba University for providing S-Tr-MAG3 and to the staff of Center for Development of Radioisotopes and Radiopharmaceuticals, National Nuclear Energy Agency, Indonesia for providing S-Bz-MAG3. The authors would like to thank Mr. S. Uchida for his technical assistance.

\section{References}

(1) V. J. Lewington, Eur. J. Nucl. Med. 20, 66 (1993).

(2) L. F. Mausner and S. C. Srivastava, Med. Phys. 20, 503 (1993).

(3) H. Vera-Ruiz, IAEA Bulletin 35, 24 (1993).

(4) W. A. Volkert and S. Jurisson, Top. Current Chem. 176, 123 (1996).

(5) K. Schwochau, Technetium-Chemistry and Radiopharmaceutical Applications, Wiley-VCH: Weinheim, 2000, pp 371-423.

(6) G. W. M. Visser, M. Gerretsen, J. D. M. Herscheid, G. B. Snow, and G. van Dongen, J. Nucl. Med. 34, 1953 (1993).

(7) S. Kinuya, K. Yokoyama, M. Kudo, Y. Kasahara, K. Kobayashi, S. Motoishi, K. Onoma, H. Bunko, T. Michigishi, and N. Tonami, J. Nucl. Med. 42, 596 (2001).

(8) S. Guhlke, A. Schaffland, P. O. Zamora, J. Sartor, D Diekmann, H. Bender, F. F. Knapp, and H.-J. Biersack, Nucl. Med. Biol. 25, 621 (1998).

(9) K. Kobayashi, S. Motoishi, K. Terunuma, A. A. Rauf, and K. Hashimoto, Radiochmistry 42, 551 (2000).

(10) A. P. Callahan, D. E. Rice, and F. F. Knapp, Jr., NucCompact 20, 3 (1989)

(11) "Preparation of kits for ${ }^{99 \mathrm{~m}} \mathrm{Tc}$ radiopharaceuticals", IAEATECDOC-649, 59 (1992).

(12) S. Pervez, A. Mushtaq, and M. Arif, J. Radioanal. Nucl. Chem. 257, 421 (2003).

(13) R. Koníŕová, M. Kohlíčková, and V. Jedináková-Křížová, J. Radioanal. Nucl. Chem. 246, 589 (2000). 